\title{
ENGINEERING DEVELOPMENT OF ADVANCED
} COAL-FIRED LOW-EMISSIONS BOILER SYSTEMS

\author{
Project Technical Status Report \\ QUARTERLY REPORT \\ For the Period of: \\ July 1996 to September 1996
}

November 1996

Submitted by:

Babcock \& Wilcox Company

Contract Research Division

1562 Beeson Street

Alliance, Ohio 44601

Prepared for:

United States Department of Energy

U.S. DOE Reference DE-AC22-92PC92160

B\&W Reference: CRD 1319

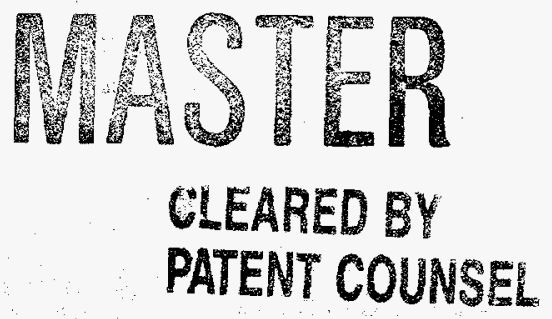




\section{DISCLAMIER}

Portions of this document may be illegibie in electronic image products. Images are produced from the best available original document. 
"This report was prepared by Babcock \& Wilcox pursuant to a contract partially funded by the U. S. Department of Energy and neither Babcock \& Wilcox, nor any of its subcontractors nor the U. S. Department of Energy, nor any person acting on behalf of either:

(a) makes any warranty or representation, expressed or implied, with respect to the accuracy, completeness, or usefulness of information contained in this report, or that the use of any information, apparatus, method, or process disclosed in this report may not infringe privately owned rights; or

(b) assumes any liabilities with respect to the use of, or for damages resulting from the use of, any information, apparatus, method or process disclosed in this report.

Reference herein to any specific commercial product, process, or service by trade name, trademark, manufacturer, or otherwise, does not necessarily constitute or imply its endorsement, recommendation, or favoring by the U. S. Department of Energy. The view and opinions of authors expressed herein do not necessarily state or reflect those of the U. S. Department of Energy." 


\section{Project Management}

\section{I.1 Summary of Activities}

Proposal efforts to the Ohio Coal Development Office (OCDO), the North Dakota Lignite Council, and the State of Illinois to gain their funding participation in the B\&W LEBS Phase IV proof-of-concept demonstration continued. Proposals were completed and submitted to the North Dakota Lignite Council (August 29,1996 - requesting \$3 million dollars) and the State of Illinois (September 30, 1996 - requesting $\$ 5$ million dollars). A visit to some North Dakota Utilities and the Lignite Research Council Director, Clifford Porter, to promote the project is scheduled for early October.

A paper entitled, "B\&W's Advanced Coal-Fired Low-Emission Boiler System; An Update on Phase II Developments," was presented at the First Joint Power and Fuel Systems Contractors Conference on July 10, 1996 in Pittsburgh, PA.

A technical paper entitled, "The Worldwide Applicability of B\&W's Advanced Coal-Fired LowEmission Boiler System," was presented at the 13th Annual International Pittsburgh Coal Conference.

The 1996 AFRC Fall International Symposium was attended where a paper entitled, "A Low-NO Burner Prototype Developed for B\&W's Advanced Coal-Fired Low-Emission Boiler System," was presented.

A technical paper entitled, "Status of Phase II Subsystem Testing in Support of B\&W's Advanced Coal-Fired Low-Emission Boiler System," was submitted for presentation at the International Joint Power Generation Conference in Huston October 14-16, 1996. 


\section{II. $\quad \mathrm{NO}_{\mathrm{x}}$ Subsystem}

The goal of the $\mathrm{NO}_{x}$ Subsystem is to achieve continuous operation of the Low-Emissions Boiler System (LEBS) at $\mathrm{NO}_{\mathrm{x}}$ emissions at or below $0.20 \mathrm{lb} / \mathrm{MBtu}$ through combustion techniques only, with a further target of $0.1 \mathrm{lb} \mathrm{NO} / \mathrm{MBtu}$ using supplementary advanced flue gas cleanup technologies if necessary. These goals places practical constraints that must be considered on the $\mathrm{NO}_{\mathrm{x}}$ Subsystem design. Not only must the boiler be designed to achieve time-temperature mixing histories that minimize $\mathrm{NO}_{x}$, but it must also be designed to operate that way throughout its working lifetime. Therefore, $\mathrm{NO}_{\mathrm{x}}$ minimization strategies must be integrated into the control systems for every boiler component from the pulverizers to the stack. Fusthermore, these goals must be met without increases in carbon loss and $\mathrm{CO}$ emissions from the levels achieved with current low- $\mathrm{NO}_{\mathrm{x}}$ combustion systems. Therefore, the $\mathrm{NO}_{\mathrm{x}}$ Subsystem requires not only sound mechanical designs of burners, furnace surface, and staging air/fuel injectors, but also sensors and software to allow control of their operation. Through engineering analysis, experimental testing, and numerical modeling in Phase II, an advanced low- $\mathrm{NO}_{\mathbf{x}}$ control system is being developed. The progress of these activities is presented in this report.

\section{II.1 Summary of Activities}

The 1996 AFRC Fall International Symposium was attended where a paper entitled, "A Low-NO Burner Prototype Developed for B\&W's Advanced Coal-Fired Low-Emission Boiler System," was presented. A lot of interest in the $\mathrm{DRB}-4 \mathrm{Z}^{\mathrm{TM}}$ burner was generated, especially in the burner's ability to fire coals with a range of fixed carbon-to-volatile matter ratio of 1.16 to 1.57 with little effect on $\mathrm{NO}_{\mathrm{x}}$ emissions.

The third and fourth rounds of burner development subsystem tests were completed this quarter. A number of hardware configurations were tested that changed the air flow distribution of the burner for improved $\mathrm{NO}_{\mathrm{x}} \mathrm{CO}$, and unburned carbon control.

Combustion modeling of the DRB- $4 Z^{\mathrm{TM}}$ burner continued at the subsystem scale for both unstaged and staged burner operation. This modeling will provide information to aid in evaluating burner performance, as well as providing input to both the commercial generating unit and proofof-concept design activities.

\section{II.2 Key Accomplishments}

\section{II.2.1 Subsystem Test Unit}

B\&W's $100 \mathrm{MBtu} / \mathrm{hr}$ Clean Environment Development Facility (CEDF) is being used as the Combustion 2000 burner development Subsystem Test Facility. The advantage of using the CEDF for Subsystem scale testing is in the ability to test a near-full size burner in an environment which closely simulates a utility boiler. 
Hardware changes and various mixing devices were tested during the third and fourth rounds of subsystem testing. Parametric testing was performed for each burner configuration. Tests were performed by varying the air distribution, primary air-to-coal ratio, furnace stoichiometry and load. The data collected were averaged over the time frame of the test and were plotted for each configuration separately, while the optimum conditions were compared collectively.

Baseline testing was performed in the CEDF utilizing the DRB- $4 Z^{\mathrm{TM}}$ low-NO $\mathrm{N}_{\mathrm{x}}$ burner firing the LEBS Illinois \#6 design coal in a previously tested configuration. The baseline tests were found to be repeatable during each round of testing.

Two coals were fired during the third and fourth rounds of burner testing, the Illinois \#6 design coal and an Ohio/Mahoning 7. A Mahoning 7A coal was previously utilized during the initial round of burner development tests. It was determined that the Mahoning 7A coal showed the most sensitivity with respect to $\mathrm{NO}_{x}, \mathrm{CO}$, and $\mathrm{UBC}$ values, therefore, it was decided to utilize this coal for the third and fourth series of tests. However, the coal supply company was mining at a different location of the seam, obtaining a coal (Ohio \#7) with a higher fixed carbon-to-volatile matter ratio. Consequently, the Ohio \#7 coal was utilized for the third and fourth rounds of testing. Table II.2.1.1 gives the coal analysis for the test coals utilized during the all of the subsystem tests thus far.

Results from the parametric tests involving changes in air distribution tended to show the same preferences for the burner configuration. By changing the air flow pattern, definite changes were noted in the emissions performance. This information corresponded to the modeling case studies, where different mixing patterns of the coal and air could be detected. Based on these results, hardware pieces were fabricated to physically change the mixing patterns which would simulate the positive influences previously seen in the experimental tests and modeling cases.

The furnace stoichiometry was varied by changing the amount of excess air to the burner through adjusting the secondary air flow. By increasing the furnace stoichiometry, more $\mathrm{O}_{2}$ was available causing more complete combustion thus resulting in lower $\mathrm{CO}$ and LOI values, while increasing the fuel-N transformation to $\mathrm{NO}_{\mathrm{x}}$. This trend was observed consistently through the test series.

Load variations were tested to simulate furnace turn-down. The visual stability of the flame was noted along with emission performance. The DRB $-4 Z^{\mathrm{TM}}$ burner did not display any problems while operating at $60 \%$ and $35 \%$ load conditions.

Figures II.2.1.1 - II.2.1.3 illustrate the $\mathrm{NO}_{\mathrm{x}}, \mathrm{CO}$, and LOI comparison for the two test burners (the benchmark DRB-XCL ${ }^{\circ}$ and the DRB-4Z ${ }^{\mathrm{TM}}$ ) firing the five different coals utilized throughout the test series. The values shown in the graphs correspond to the optimum burner configuration for the DRB-4Z $Z^{\mathrm{TM}}$ and the DRB-XCL ${ }^{\otimes}$ burners. Figure II.2.1.1 shows the reduction in $\mathrm{NO}_{\mathrm{x}}$ achieved by the $\mathrm{DRB}-4 Z^{\mathrm{TM}}$ burner. $\mathrm{NO}_{\mathrm{x}}$ reductions for the Illinois coal range between $20-25 \%$, for the Mahoning coal between $40-50 \%$, and for the Horizon coal between $50-55 \%$. The Kentucky \#9 and the Ohio \#7 coal were not fired with the DRB-XCL ${ }^{\bullet}$ burner, therefore, no comparison can be made for these coals between the DRB- $4 Z^{\mathrm{TM}}$ and the DRB-XCL ${ }^{\circ}$ burners. 
The test coals ranged in fixed carbon-to-volatile matter ratios from 1.16 to 1.57 , as shown in Table II.2.1.1. It is evident from Figure II.2.1.1, that the effect of firing the various coals on $\mathrm{NO}_{x}$ emission for the DRB- $4 Z^{\mathrm{TM}}$ burner is relatively flat across the entire range.

The effect on the $\mathrm{CO}$ emissions is illustrated in Figure II.2.1.2. The $\mathrm{CO}$ emissions while firing the Mahoning coal were greatly increased for the $\mathrm{DRB}-4 \mathrm{Z}^{\mathrm{TM}}$ burner, as could be expected due to the significant $\mathrm{NO}_{\mathrm{x}}$ reduction. However, looking at the Ohio Horizon coal results, although the $\mathrm{NO}_{\mathrm{x}}$ was significantly reduced with the DRB- $4 Z^{\mathrm{TM}}$ burner, the $\mathrm{CO}$ emissions were not as greatly affected, with the average remaining around $50 \mathrm{ppm}$. CO emissions for the Kentucky \#9 and Ohio \#7 coals remained in the same general range as the Illinois \#6 and Ohio Horizon coals... Again, it should be noted that the values reported on the graphs are for the optimum burner configurations for that particular test series, firing the various coals. These graphs do not necessarily represent the average values obtained over the wide variety of test configurations.

Table II.2.1.1: Chemical Analysis of Test Coals

\begin{tabular}{|c|c|c|c|c|c|c|c|c|c|c|}
\hline & \multicolumn{2}{|c|}{$\operatorname{lil}_{10018}=6$} & \multicolumn{2}{|c|}{ Wuroning } & \multicolumn{2}{|c|}{ irentuchy } & \multicolumn{2}{|c|}{$60170 \%$} & \multicolumn{2}{|c|}{$9110 \% 10,1001$} \\
\hline & 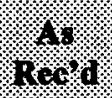 & Dos & $84_{1}^{4}$ & $\sqrt[10]{4}$ & 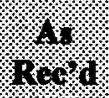 & 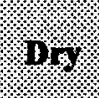 & (redil. & 106. & 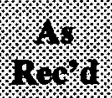 & $101 \%$ \\
\hline \multicolumn{11}{|l|}{ Proximate Analysis, \% } \\
\hline Moisture & 14.25 & - & 5.70 & - & 9.82 & - & 3.90 & - & 5.51 & - \\
\hline Volatile Matter & 36.14 & 42.15 & 37.85 & 40.14 & 35.07 & 38.89 & 34.49 & 35.89 & 38.25 & 40.48 \\
\hline Fixed Carbon & 41.81 & 48.75 & 49.98 & 53.00 & 44.41 & 49.24 & 54.32 & 56.52 & 46.27 & 48.97 \\
\hline Ash & 80 & 9.10 & 6.47 & 6.86 & 10.70 & 11.87 & 7.29 & 7.59 & 9.97 & 10.55 \\
\hline Gross Heating Value & 10980 & 12805 & 13120 & 13913 & 1129 & 12452 & 13292 & 13831 & 12221 & 12934 \\
\hline Btu/lb (M\&A Free) & - & 14087 & - & 14938 & $=$ & 14129 & - & 14967 & - & 14459 \\
\hline FCNM & \multicolumn{2}{|c|}{1.16} & \multicolumn{2}{|c|}{1.32} & \multicolumn{2}{|c|}{1.27} & \multicolumn{2}{|c|}{1.57} & \multicolumn{2}{|c|}{1.21} \\
\hline \multicolumn{11}{|l|}{ Ultimate Analysis, \% } \\
\hline Moisture & 14.25 & - & 5.70 & - & 9.82 & - & 3.90 & - & 5.51 & - \\
\hline Carbon & 60.56 & 70.62 & 73.63 & 78.08 & 61.74 & 68.46 & 74.10 & 77.11 & 66.69 & 70.58 \\
\hline Hydrogen & 4.54 & 5.29 & 4.98 & 5.28 & 4.42 & 4.90 & 5.21 & 5.42 & 5.05 & 5.34 \\
\hline Nitrogen & 1.13 & 1.32 & 1.56 & 1.66 & 1.42 & 1.57 & 1.30 & 1.35 & 1.38 & 1.46 \\
\hline Sulfur & 3.50 & 4.08 & 0.93 & 0.99 & 4.5 & 5.05 & 1.22 & 1.27 & 3.88 & 4.11 \\
\hline Ash & 7.80 & 9.10 & 6.47 & 6.86 & 10.70 & 11.87 & 7.29 & 7.59 & 9.97 & 10.55 \\
\hline Oxygen (by difference) & 8.22 & 9.59 & 6.73 & 7.13 & 7.35 & 8.15 & 6.98 & 7.26 & 7.52 & 7.96 \\
\hline
\end{tabular}




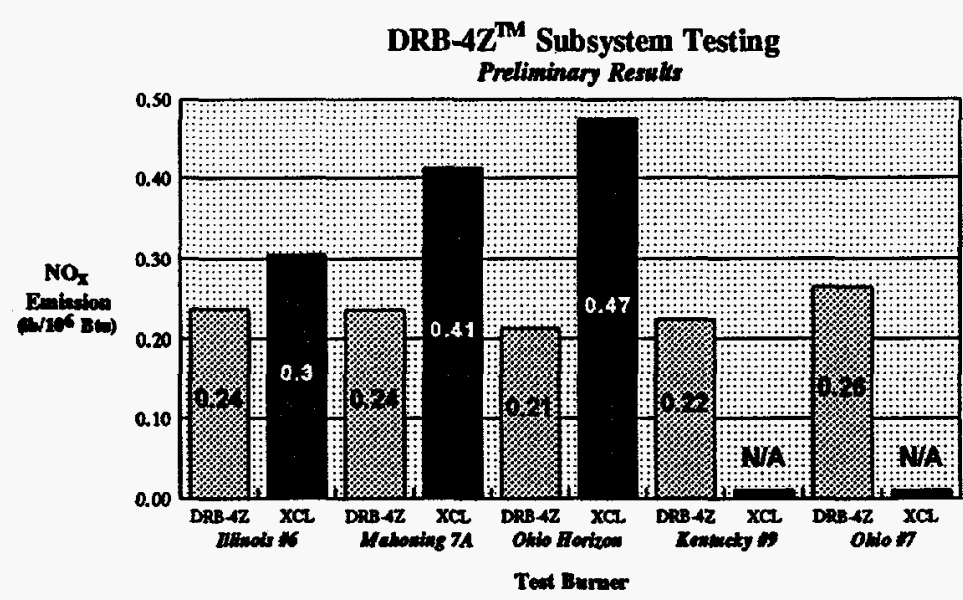

Figure II.2.1.1 NO Emission Comparison to Test Burner Firing Five Test Coals

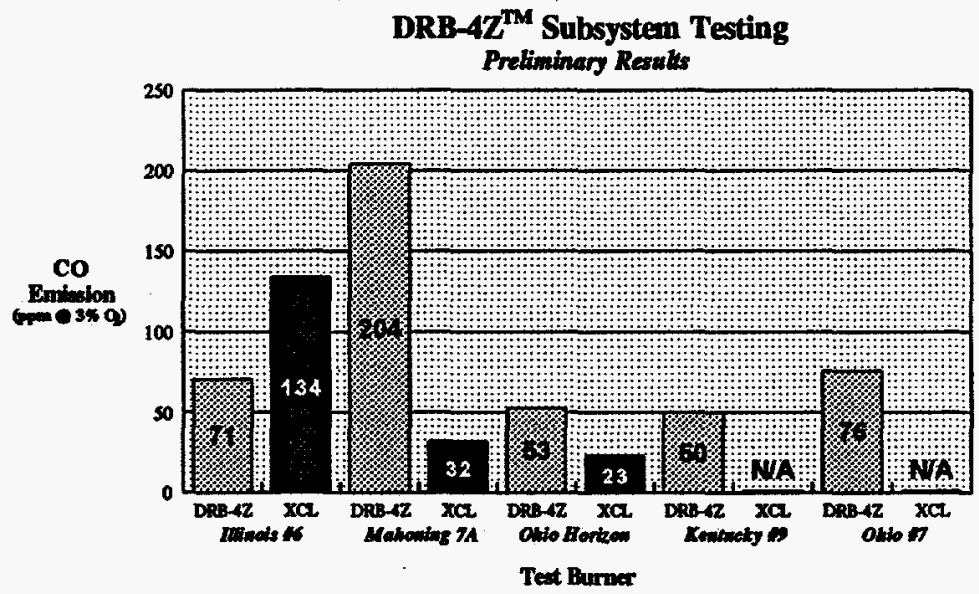

Figure II.2.1.2 CO Emission Comparison to Test Burner Firing Five Test Coals

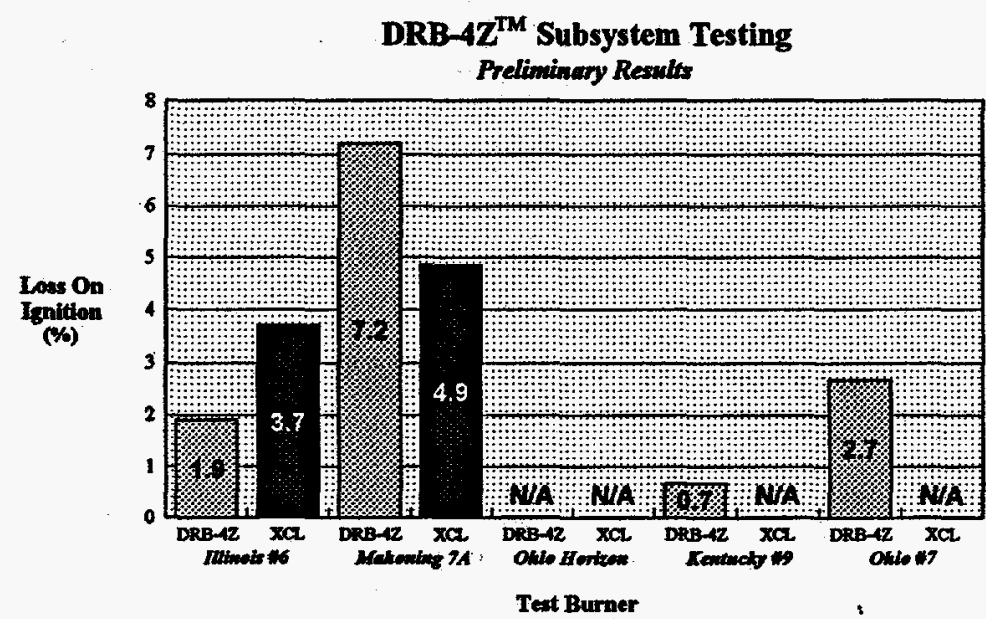

Figure II.2.1.3 LOI Comparison to Test Burner Firing Five Test Coals 
The LOI values, shown in Figure II.2.1.3 correspond to the $\mathrm{CO}$ emissions. The cases where lower CO emissions were obtained, lower LOI values were also measured. LOI data was not collected while firing the Ohio Horizon coal for either test burner. All fly ash samples collected were measured for loss on ignition at $1380^{\circ} \mathrm{F}$. A few random samples were also measured for unburned carbon determined by an ASTM method. A comparison between the two measurements showed that the LOI measurements were on the average $7 \%$ higher than the UBC measurements.

Additional coals will be tested during the fifth round of Subsystem Testing scheduled for late October. An eastern bituminous with a higher fixed carbon-to-volatile matter ratio and a western sub-bituminous coal will be fired with the DRB- $4 Z^{\mathrm{TM}}$ burner.

Numerical modeling continued to be used to provide insight into unstaged and staged performance of the DRB- $4 Z^{\mathrm{TM}}$ burner, and to evaluate NOx reduction for deeply staged burner operation. A series of burner models were begun this quarter to compare unstaged combustion characteristics of the burner with staged combustion at a burner stoichiometry of 0.85 and 0.75 . These models are also being used to compare carbon monoxide concentrations and carbon burnout, both in the burner near-field and in the overfire air zone. This information will be compared with measured trends obtained during subsystem testing to provide information for the deep-staging designs for the commercial generating unit and the proof-of-concept facility. 


\section{III. $\mathrm{SO}_{2}$ /Particulate/Air Toxics/Solid By-Product Subsystem}

The scope of the $\mathrm{SO}_{2}$ subsystem comprises the control of $\mathrm{SO}_{2}$, particulate matter, hazardous air pollutants (commonly called "air toxics"), and solid byproducts from the B\&W LEBS plant. The specific minimum performance requirements for the $\mathrm{SO}_{2}$ subsystem are:

- $\mathrm{SO}_{\mathrm{x}}$ - Less than $0.20 \mathrm{lb}$ ( $\mathrm{SO}_{2}$ equivalent)/MBtu for coals with sulfur levels of $3 \mathrm{lb}$ of sulfur per MBtu and no more than 0.067 times the sulfur content (lb/MBtu) for coals with less than $3 \mathrm{lb}$ of sulfur per MBtu.

- Particulate -- Less than $0.015 \mathrm{lb}$ particulate/MBtu

- Potential to comply with possible emissions control regulations for targeted air toxics.

- Produce environmentally benign solid byproduct.

- Integrate with other plant subsystems to yield optimal overall performance and cost.

In addition, the following performance targets have been established:

- $\mathrm{SO}_{\mathrm{x}}$-- Less than $0.10 \mathrm{lb}$ ( $\mathrm{SO}_{2}$ equivalent)/MBtu for coals with sulfur levels of $3 \mathrm{lb}$ of sulfur per MBtu and no more than 0.0333 times the sulfur content (lb/MBtu) for coals with less than $3 \mathrm{lb}$ of sulfur per MBtu.

- Particulate - Less than $0.01 \mathrm{lb}$ particulate/MBtu (B\&W plans to achieve $0.005 \mathrm{lb} / \mathrm{MBtu}$ )

On the basis of the results compiled during the concept selection process completed in Phase I, the Limestone Injection Dry Scrubbing (LIDS) process was selected for further development and evaluation in B\&W's LEBS project. The LIDS process is a cost-effective integration of three commercially proven flue gas cleanup technologies: furnace limestone injection, dry scrubbing, and pulse-jet fabric filtration. Through engineering analysis, experimental testing, and numerical modeling, a LIDS process is being developed that is capable of ultra-high $\mathrm{SO}_{2}$ removal and superior particulate control while addressing the potential issues of air toxic emissions and solid byproduct utilization. The progress of the LIDS activities follows.

\section{III.1 Summary of Activities}

The solid by-product cognizance effort continued. $\mathrm{B} \& \mathrm{~W}$ is aggressively pursuing ways to reduce or utilize the solid waste produced by its various clean coal and FGD processes through a variety of in-house and externally-funded development programs. Specific plans for E-LIDSTM solid byproduct utilization tests were completed. The Energy and Environmental Research Center (EERC - University of North Dakota) will be completing utilization tests and economics on the E-

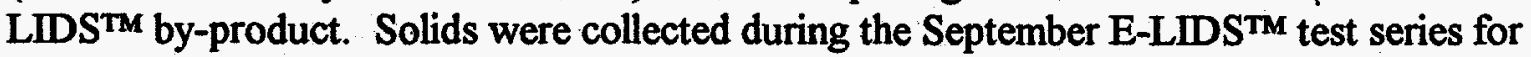
analysis and use in demonstrating the utilization methods. (Task 7.1)

The air toxics cognizance effort continued. B\&W is conducting a wide variety of air toxicsrelated research projects, and is closely following the regulatory process. The effort will continue throughout the project. (Task 7.1) 
Numerical flow modeling of the commercial dry scrubber model was completed. The model was used to evaluate design variations, with predictions for impact on pressure drop, wall impingement, and mixing. Two alternate outlet geometries were modeled to evaluate the impact of the outlet configuration on the vessel flow patterns and sorbent particle distribution. (Task 7.3)

Data reduction and analysis for the second round of Phase II $100 \mathrm{MBtu} / \mathrm{hr}$ E-LIDS testing (June 1996) was completed. The test series focused on achieving ultra-high $\mathrm{SO}_{2}$ capture, obtaining $\mathrm{SO}_{2}$ performance curves with a fine limestone, and observing system operability. This effort is covered under the key accomplishment section. (Task 11.2)

The third and final round of Phase II E-LIDS testing was successfully completed September 16 25, 1996, at $100 \mathrm{MBtu} / \mathrm{hr}$ in the Clean Environment Development Facility. The test series focused on repeating the ultra-high $\mathrm{SO}_{2}$ removal achieved in the June 1996 test series, obtaining $\mathrm{SO}_{2}$ performance curves using a coarser limestone, completing air toxic measurements, and addressing the effect of low-load operation on furnace limestone injection performance. This effort is covered under the key accomplishment section (Task $11.1 \& 11.2$ )

\section{III.2 Key Accomplishments}

\section{III.2.1 - E-LIDS Subsystem Test Series \#2 Data Reduction Completed}

Data reduction and analysis for the second round of Phase II $100 \mathrm{MBtu} / \mathrm{hr}$ E-LIDS testing (June 1996) was completed. The test series focused on achieving ultra-high $\mathrm{SO}_{2}$ capture, obtaining $\mathrm{SO}_{2}$ performance curves with a fine limestone, and observing system operability.

The LEBS goal of $0.10 \mathrm{lb} \mathrm{SO} \mathrm{SO}_{2} \mathrm{MBtu}\left(98 \% \mathrm{SO}_{2}\right.$ removal) was achieved with the E-LIDS system. Figure III.2.1.1 shows the total $\mathrm{SO}_{2}$ removal that was achieved at the outlet of each of the ELIDS unit operations. At the outlet of the furnace limestone injection system, $38 \% \mathrm{SO}_{2}$ removal was achieved. At the outlet of the dry scrubber, $77 \% \mathrm{SO}_{2}$ removal was achieved. At the outlet of the baghouse (or the E-LIDS system outlet) $99 \% \mathrm{SO}_{2}$ removal was achieved. The operating conditions for this test included: 1) furnace stoichiometric ratio (Ca/S);1.35 mol Ca/mol S, 2) approach to flue gas saturation temperature; $10^{\circ} \mathrm{F}, 3$ ) slurry percent solids concentration; $30-35 \%$, and 4) limestone grind; 6 microns mass mean diameter. 


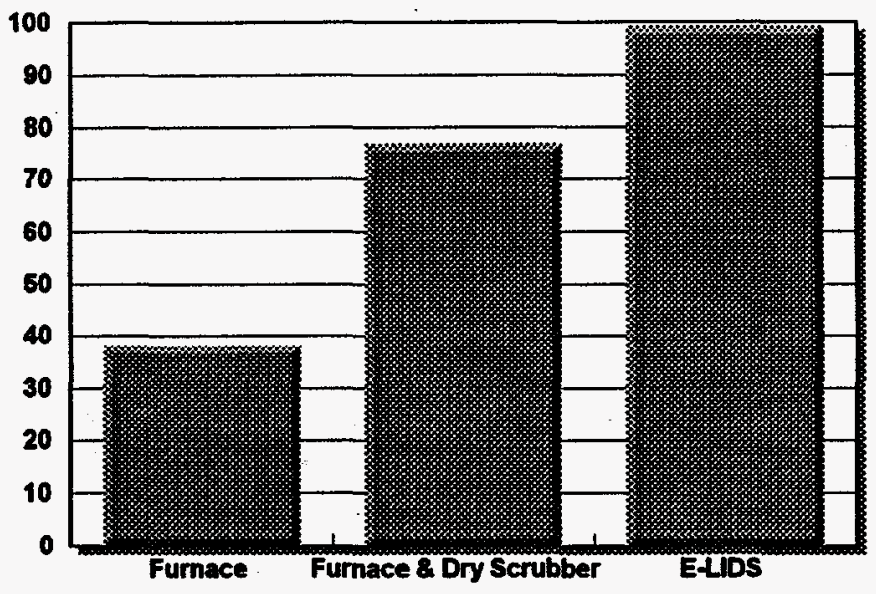

Figure III.2.1.1 - 10 MW. E-LIDS Total $\mathrm{SO}_{2}$ Removal June test series - 6 micron limestone

Another way to express E-LIDS $\mathrm{SO}_{2}$ capture is by the percentage of the total $\mathrm{SO}_{2}$ (created from the coal) that is removed with each unit operation or that goes up the stack. Figure III.2.1.2 shows that for $2578 \mathrm{ppm}$ produced from the coal, $\mathrm{SO}_{2}$ capture occurred as follows (for the same conditions as the data shown in Figure III.2.1.1): 38.0\% (967 ppm) in the furnace, 38.8\% (989 $\mathrm{ppm})$ in the dry scrubber, $22.6 \%(575 \mathrm{ppm})$ in the baghouse, and $0.7 \%(17 \mathrm{ppm})$ went up the stack.

Figure III.2.1.3 shows the furnace $\mathrm{SO}_{2}$ removals achieved as a function of furnace calcium stoichiometry $(\mathrm{Ca} / \mathrm{S})$. The furnace $\mathrm{SO}_{2}$ removal ranged from 32 to $39 \%$. A range of removals may occur at a given $\mathrm{Ca} / \mathrm{S}$ due to sootblowing frequency and the resulting swings in convection pass temperature.

Figure III.2.1.4 shows the $\mathrm{SO}_{2}$ removals obtained versus approach to saturation temperature (Tas) for the dry scrubber, baghouse and total E-LIDS systems. The figure clearly shows that low operating temperatures enhance $\mathrm{SO}_{2}$ capture in the dry scrubber, baghouse, and therefore, the overall E-LIDS systems. The high baghouse $\mathrm{SO}_{2}$ removal achieved at low dry scrubber/baghouse operating temperatures is a necessary ingredient for the E-LIDS final $\mathrm{SO}_{2}$ emissions trim. 


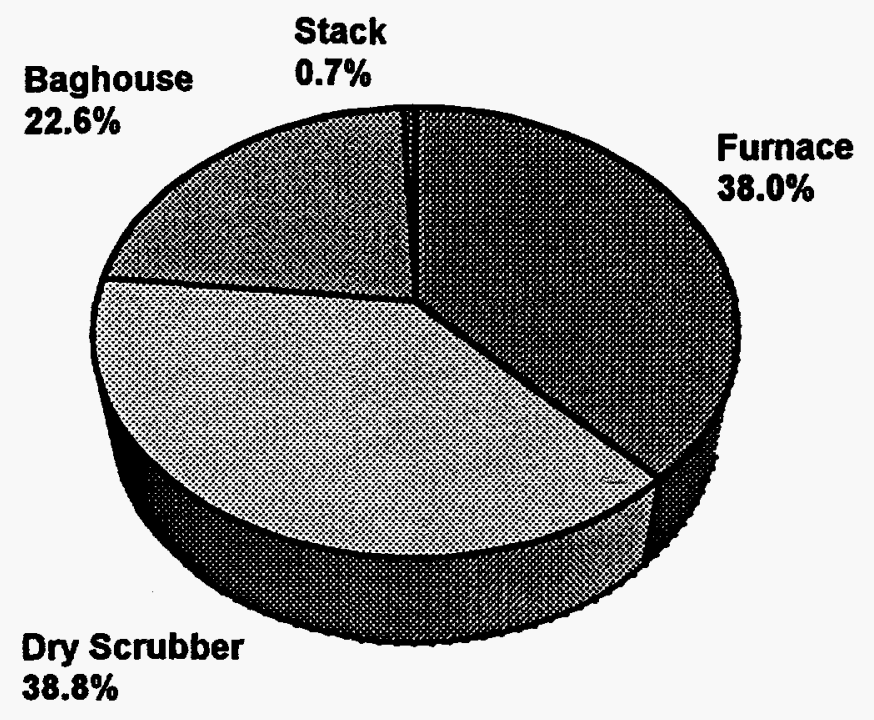

Figure III.2.1.2 10 MWe E-LIDS SO2 Removal by Unit Operation June test series - 6 micron limestone

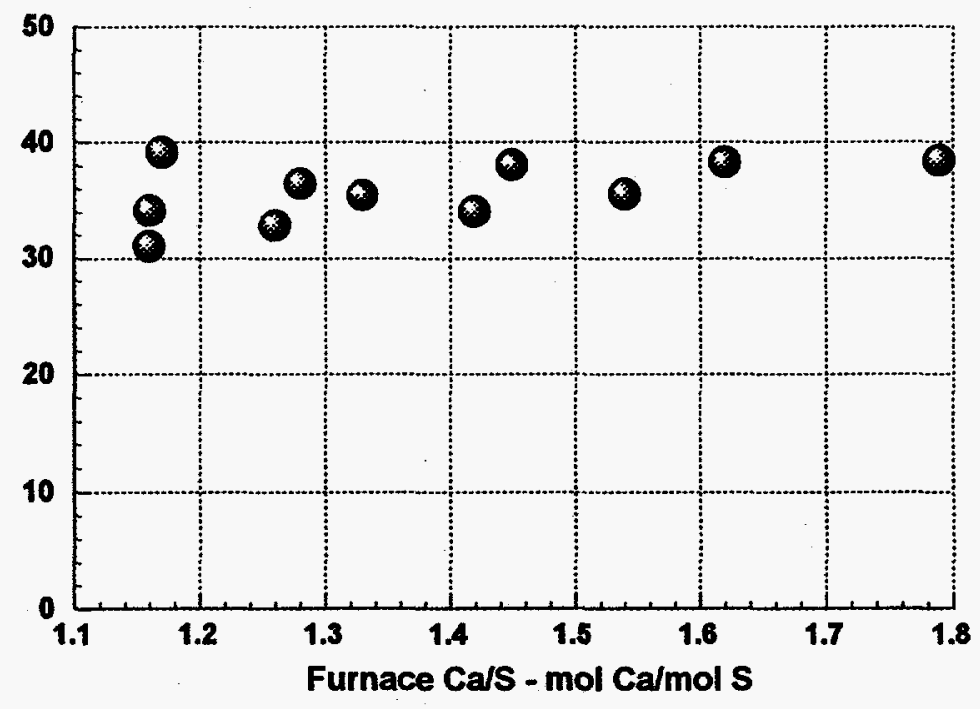

Figure III.2.1.3 - 10 MWe E-LIDS Furnace $\mathrm{SO}_{2}$ Removal versus $\mathrm{Ca} / \mathrm{S}$ June test series - 6 micron limestone

Page III - 4 


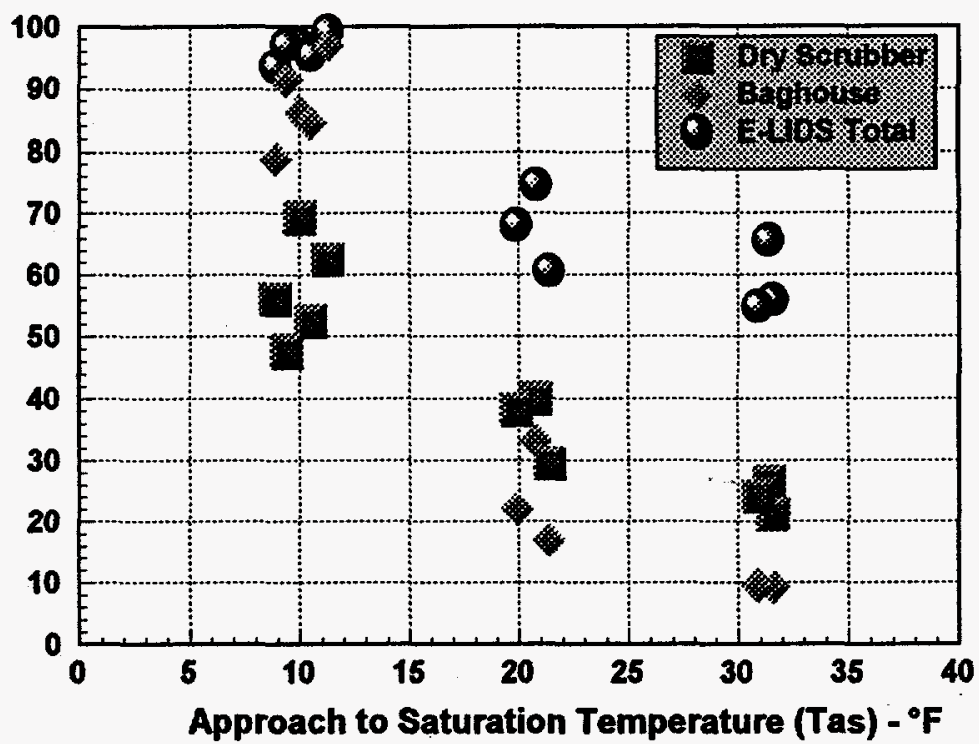

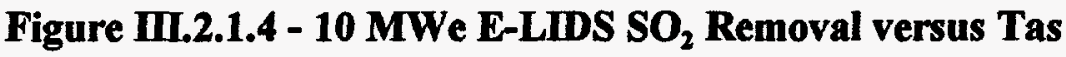
June test series - 6 micron limestone

\section{III.2.2 - E-LIDS Subsystem Test Series \#3 Completed}

The third round of $100 \mathrm{MBtu} / \mathrm{hr}$ E-LIDS tests were completed in late September 1996. Goals of the test series included: 1) achieve $98 \% \mathrm{SO}_{2}$ removal while using a limestone with a grind between 15 and 20 microns mass mean diameter, 2) quantify the effects of low-load operation on furnace limestone injection performance, and 3) make air toxics measurements.

Coarser limestone grind. All of the $100 \mathrm{MBtu} / \mathrm{hr}$ E-LIDS test during the first and second ELIDS test series had used a limestone with a grind of less than 10 microns mass mean diameter (MMD). In the third round of tests coarser limestone was tested to prove that ultra-high $\mathrm{SO}_{2}$ removal (98\%) should be achieved while using a limestone between 15 and 20 microns MMD. This goal is important to the process in order to improve the E-LIDS system economics and operability. A coarser limestone will do the following: 1)decrease the auxiliary power necessary to grind the limestone, hence, increase the cost-effectiveness of the E-LIDS system and 2)decrease the amount of convection pass fouling associated with limestone adhering to the tubes.

Low load-operation. The effects of low-load operation on the furnace limestone injection process was investigated. This information will be used to determine operating procedures covering the entire load range.

Air toxics measurements. Air toxics measurements were made at the inlet to the dry scrubber, inlet to the baghouse, and at the stack during E-LIDS operation. Measurements of total mercury, speciated mercury, trace metals, and acid gases were collected to confirm the systems capability 
to achieve greater than $90 \%$ mercury removal and to further characterize the E-LIDS system's air toxics removal capabilities.

Data reduction and analysis will occur during the next quarter of the project. Results from the September 1996 E-LIDS tests will be presented in the next quarterly report. 


\section{Boiler Subsystem}

At the heart of the LEBS is the boiler. Within this advanced B\&W boiler, all of the low emission technologies are integrated. To meet the net plant efficiency goal of $42 \%$, the boiler must be designed not only to achieve the proper conditions for low $\mathrm{NO}_{\mathrm{x}}$ combustion with air staging and accommodate the in-furnace injection of the limestone for the LIDS process, but it must also efficiently capture the heat to produce high temperature steam at well above critical pressure. The steam conditions selected for the boiler are $4500 \mathrm{psi}, 1100^{\circ} \mathrm{F} / 1100^{\circ} \mathrm{F} / 1100^{\circ} \mathrm{F}$.

Since the steam-side pressure and main and reheat steam temperatures are highex than conventional cycles and operation of low $\mathrm{NO}_{\mathrm{x}}$ burners creates sub-stoichiometric conditions in portions the furnace, additional challenges are presented. Higher alloy materials must be used in the outlet portions of the superheater and reheater banks to obtain acceptable surface metal temperatures. In addition, materials must be selected that will resist corrosion since the surface of these outlet tubes will operate at temperatures which will allow the coal ash to remain molten on their surfaces. Consideration must also be given to furnace wall corrosion in the combustion zone. Thus, boiler design work has been identified to address the integration of the $\mathrm{NO}_{\mathrm{x}}$ and $\mathrm{SO}_{2}$ subsystems while applying B\&W's advanced supercritical boiler technology.

\section{IV.1 Summary of Activities}

\section{IV.1.1 CGU Boiler Development}

Surface for the boiler was reset after receiving reheat control load from Raytheon. Reheat control load has been defined as $60 \%$ MCR. Other modifications were also added to compensate for the low furnace exit gas temperature and the integration of the LIDS system.

\section{IV.2 Key Accomplishments}

\section{IV.2.1 CGU Boiler Development}

After receiving the reheat control load from Raytheon, work began to finalize the boiler design. In order to maintain steam temperature at control load, the surface for reheat 2 was over surfaced for full load in order to achieve control load steam temperature. Originally our concept was to control reheat 1 temperature by gas biasing and allow spray to control reheat 2 temperature at full load. After setting surface it was discovered that the amount of spray required for reheat 2 at full load would have a significant impact on cycle efficiency. Several options were investigated for reducing the spray required. The method finally settled on was to use steam bypassing on the second stage reheater at full load. In this control method, more than half of the reheat 2 steam flow bypasses the surface in the horizontal down pass and is remixed before the pendant surface. It is believed this method will be economical and easily controlled while eliminating the need for any reheat spray for temperature control. 
Efforts continue on the circulation analysis for a vertical tube furnace. This furnace arrangement would significantly reduce the pressure drop for the main steam through the boiler. However, tube overheat problems are being encountered as well as stability. We are uncertain at this point if this type of furnace is feasible. In parallel, a spiral wound furnace is also being analyzed.

Due to the furnace size and overfire air for NOx reduction, the Furnace Exit Gas Temperature (FEGT) is lower than desired. At this time we are designing for refractory being applied in the upper furnace area to increase the FEGT. Other methods are being sought to overcome this problem, but thus far refractory seems to be our only alternative.

\section{IV.2.2 Corrosion Evaluation}

The two expanded laboratory tests have been commenced during the last quarter. The first test involves exposure of candidate furnace-wall alloys and coatings to a simulated low- $\mathrm{NO}_{\mathrm{x}}$ combustion gas for 5000 hours at $1300^{\circ} \mathrm{F}$, and the second test is performed under the same environment but at $1500^{\circ} \mathrm{F}$. The tests will be completed in January and February 1997, respectively.

Fabrication of a corrosion test panel for Unit \#2 of Allegheny Power Systems at the. Hatfield's Ferry Power Station is also underway. The 20-tube $\times 20$-foot panel will consist of eight different commercial coatings and bare T2 sections. The panel fabrication is expected to complete in February 1997, and the installation will follow during the Unit \#2 Spring outage. Following the installation, $\mathrm{B} \& \mathrm{~W}$ will monitor and analyze the corrosion performance of this panel during the next three scheduled outages. The cost for the analysis will be paid for by the Electric Power Research Institute under a separate contract. 


\section{Balance of Plant Subsystem}

In order to develop an overall plant design and to evaluate plant efficiency and cost, B\&W subcontracted with Raytheon Engineers and Constructors of Denver, Colorado. Together a Phase I concept was developed that achieved the initial LEBS goal of $38 \%$ net plant efficiency. That design resulted in identification of a number of potential improvements to the turbine cycle and auxiliary equipment needed to meet the Phase II goal of $42 \%$ net plant efficiency.

\section{V.1 Summary of Activities}

Turbine heat balances for full load and reheat control load have been issued for HARP and nonHARP cycles. An economic analysis has also been performed comparing the two.

The economic analysis to compare on sight limestone grinding against purchasing prepared limestone has been completed.

\section{V.2 Key Accomplishments}

Heat balances for full and reheat control (60\%) loads for both the HARP and non-HARP cycles were completed. The HARP cycle had a better heat rate by only eleven Btu/kWh. An economic analysis was performed to evaluate both cycles on a cost of electricity basis. The non-HARP cycle was the clear economic choice for plant design because the higher equipment costs associated with the HARP configuration outweighed the small heat rate improvement. Consequently, the non-HARP cycle has been selected for the CGU design.

The evaluation for grinding limestone or purchasing prepared limestone is now completed. Based on this evaluation, the CGU will be designed based on prepared limestone being purchased in lieu of on site grinding. This option saves plant space, maintenance cost, and auxiliary power for grinding equipment. 


\section{Controls \& Sensors Subsystem}

In order to maintain low stack emissions and optimum boiler performance throughout the operating range and lifetime of the LEBS, a state-of-the-art integrated control system must be developed. This control system must include new sensors as well as old sensors used in new ways. It must make sense out of the data provided while initiating or directing the operator to take appropriate action. The control system that will help assure that the LEBS will meet its stack emission, efficiency, availability, and cost of electricity goals.

The overall philosophy of the LEBS control system is to use conventional, state-of-the-art solutions to satisfy new control requirements. Existing sensors, hardware, and software are specified whenever possible and new measurements or advanced equipment are recommended for development only where necessary to assure the success of the project. The progress of the Controls \& Sensors Subsystem is contained in this report.

\section{VI.1 Summary of Activities}

PC network problems on the use of the X-terminal connection between Barberton and Alliance were resolved permitting the SPEEDUP process model in Alliance to be run from Barberton. A simplified control scheme was applied to the process model which identified discrepancies in both SPEEDUP and the process model which were resolved. A test matrix was established for a parametric evaluation of the combustion/NOx portion of the POC process model and initial tests were conducted.

\section{VI.2 Key Accomplishments}

Work started on control system design using the preliminary simulator of the POC facility developed using the SPEEDUP dynamic modeling package. Secondary and overfire air flow controllers were implemented using a parallel type PID algorithm which is widely used by control vendors in the utility industry.

An open loop parametric study was conducted based on a matrix containing important input parameters - coal flow, primary and secondary air flows. The study was conducted at the condition which represents full load of the POC facility to determine the relationship between emissions parameters and input parameters. Emissions parameters monitored were excess oxygen $\left(\mathrm{O}_{2}\right)$, carbon monoxide $(\mathrm{CO})$, nitrous oxide $(\mathrm{NO})$, sulfur dioxide $\left(\mathrm{SO}_{2}\right)$, Economizer outlet gas temperature, and unburned carbon (UBC).

Table VI.2.1 shows the matrix of tests performed on first group of burners: 
Table VI.2.1: $\quad$ Parametric Study Test Matrix

\begin{tabular}{|c|c|c|c|}
\hline \multicolumn{4}{|c|}{ Parametric Study Test Matrix } \\
\hline & 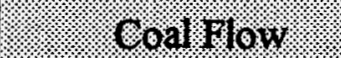 & 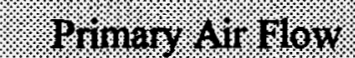 & 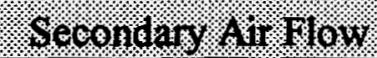 \\
\hline 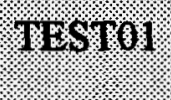 & & & $\begin{array}{l}1 \text { - 10\% Step Decrease } \\
2-10 \% \text { Step Increase }\end{array}$ \\
\hline$\% 10102$ & & $\begin{array}{l}1 \text { - 10\% Step Decrease } \\
2 \text { - 10\% Step Increase }\end{array}$ & \\
\hline 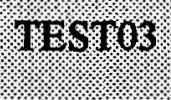 & $a_{-}$ & $\begin{array}{l}1-10 \% \text { Step Decrease } \\
2-10 \% \text { Step Increase }\end{array}$ & $\begin{array}{l}1-10 \% \text { Step Decrease } \\
2-10 \% \text { Step Increase }\end{array}$ \\
\hline 1.5.5704: & $\begin{array}{l}1 \text { - } 10 \% \text { Step Decrease } \\
2-10 \% \text { Step Increase }\end{array}$ & & \\
\hline 159105 & $\begin{array}{l}1-10 \% \text { Step Decrease } \\
2-10 \% \text { Step Increase }\end{array}$ & & $\begin{array}{l}1-10 \% \text { Step Decrease } \\
2-10 \% \text { Step Increase }\end{array}$ \\
\hline $14 \mathrm{SH} 106$ & $\begin{array}{l}1 \text { - 10\% Step Decrease } \\
2-10 \% \text { Step Increase }\end{array}$ & $\begin{array}{l}1-10 \% \text { Step Decrease } \\
2-10 \% \text { Step Increase }\end{array}$ & \\
\hline $105 \mathrm{srOH}$ & $\begin{array}{l}1-10 \% \text { Step Decrease } \\
2-10 \% \text { Step Increase }\end{array}$ & $\begin{array}{l}1-10 \% \text { Step Decrease } \\
2-10 \% \text { Step Increase }\end{array}$ & $\begin{array}{l}1-10 \% \text { Step Decrease } \\
2-10 \% \text { Step Increase }\end{array}$ \\
\hline
\end{tabular}

Following is the description of coordinated control test involving a simultaneous step change in all three parameters (TEST07). Figure VI.2.1 shows changes in the input parameters and Figure VI.2.2 shows the response in the gas emissions parameters.

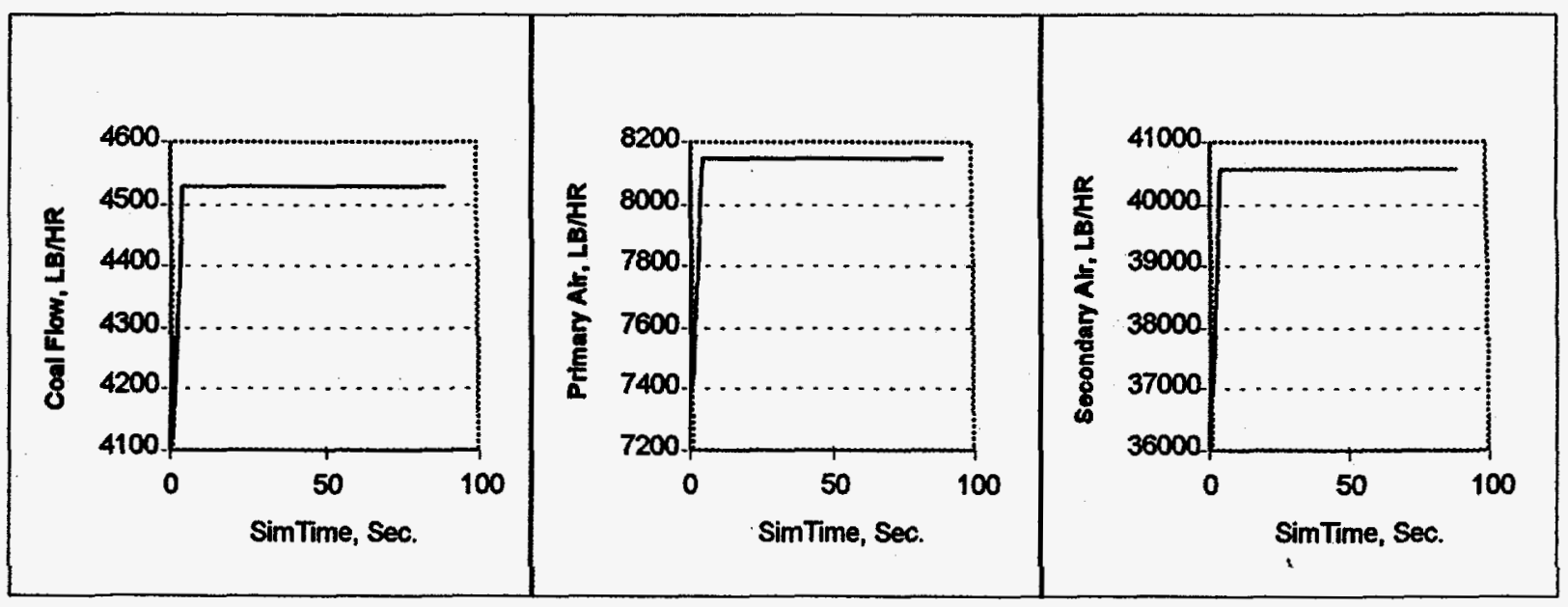

Figure VI.2.1 - Gas Input Parameters 

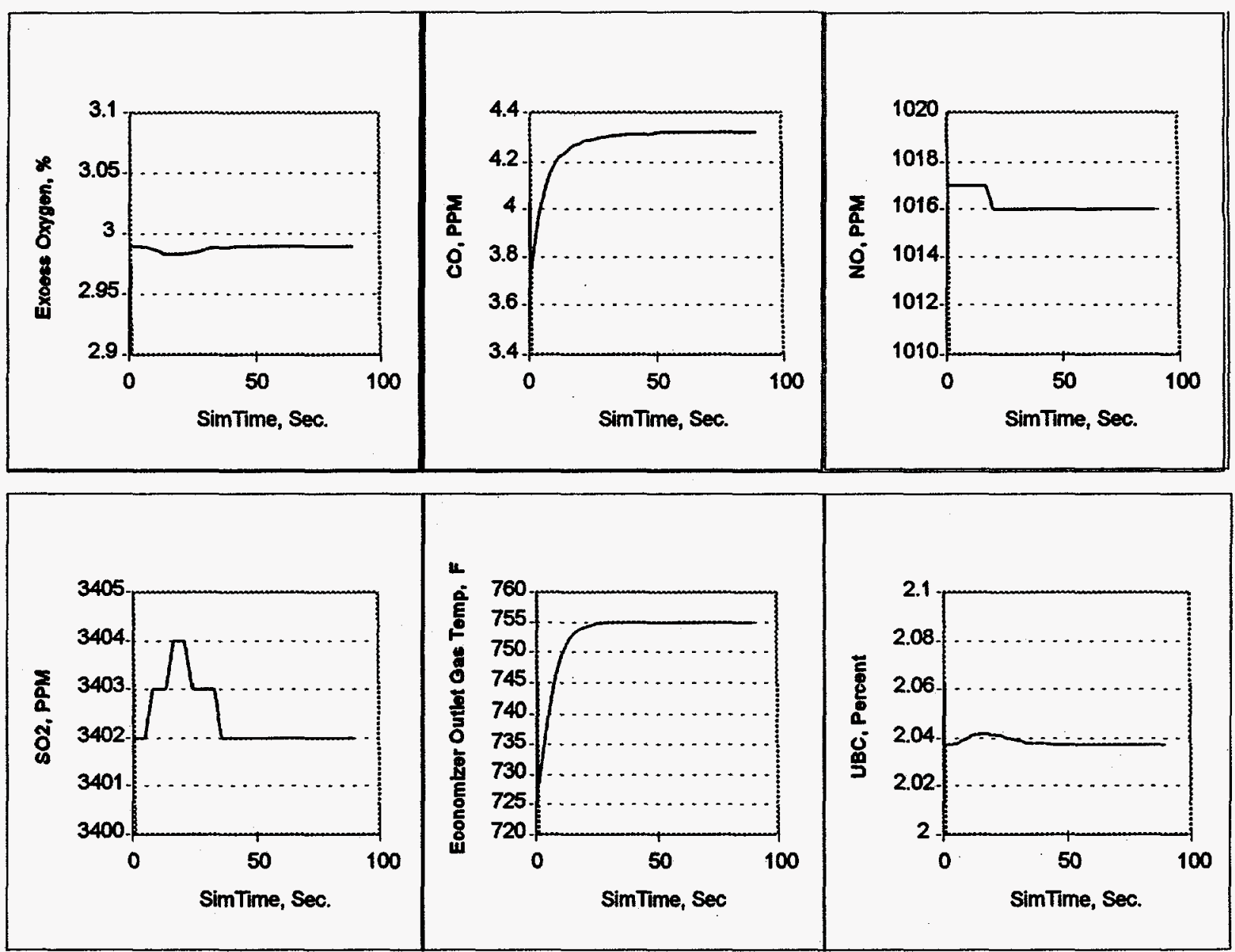

Figure VI.2.2 - Gas Emission Parameters

Page VI - 3 